\title{
Environmental management performance for brazilian industrials: measuring with the item response theory
}

\author{
Andréa Cristina Trierweiller ${ }^{\mathrm{a},{ }^{*}}$, Blênio César Severo Peixe ${ }^{\mathrm{b}}$, Rafael Tezza ${ }^{\mathrm{c}}$, Antonio Cezar Bornia ${ }^{\mathrm{d}}$, \\ Dalton Francisco de Andrade ${ }^{\mathrm{e}}$ and Lucila Maria de Souza Campos ${ }^{\mathrm{f}}$ \\ abdef Production Engineering Department, Federal University of Santa Catarina, Florianópolis, SC, Brazil \\ ${ }^{c}$ Department of Business Administration, Santa Catarina State University, Florianópolis, SC, Brazil
}

\begin{abstract}
Growing challenges with respect to preserving the environment have forced changes in company operational structures. Thus, the objective of this article is to measure the evidence of Environmental Management using the Item Response Theory, based on website analysis from Brazilian industrial companies from sectors defined through the scope of the research. This is a qualitative, exploratory, and descriptive study related to an information collection and analysis instrument. The general view of the research problem with respect to the phenomenon under study in based on multi-case studies, with the methodological outline based on the theoretical reference used. Primary data was gathered from 270 company websites from 7 different Brazilian sectors and led to the creation of 26 items approved by environmental specialists. The results were attained with the measuring of Environmental Management evidence via the Item Response Theory, providing a clear order of the items involved based on each item's level of difficulty, quality, and propriety. This permitted the measurement of each item's quality and propriety, as well as that of the respondents, placing them on the same analysis scale. Increasing the number of items and companies involved is suggested fEor future research in order to permit broader sector analysis.
\end{abstract}

Keywords: Environmental management performance, Industry websites, Disclosure, Measurement, Item response theory

\section{Introduction}

The increasing challenge of preserving the environment has forces readjustments in the industrial companies' operational structures. However, these transformation have not occurred merely within manufacturing processes, but also in their management paradigms, in which new concepts must be incorporated in order to attend an ever demanding society with respect to preserving the environment, an increased gamut of legislation, and extremely competitive markets, in which environmental certification is an indispensible condition to negotiating [3, 13, 19, 20]. There are also the stakeholders who are exercising the fundamental role of pressuring organizations towards continued process improvement and perfection.
In recent decades preserving and restoring the environment has become a worldwide concern. In Brazil, this concern is explicitly expressed in the 1988 Federal Constitution [9] in Article 225. It states that "everyone has the right to an ecologically balanced environment of common use, essential to a healthy quality of life, necessitating the government and society the duty to defend and preserve it for present and future generations." Furthermore, Article 23 of the same constitution states "common responsibility of Federal, State, Federal District and Municipalities: (...) VI - protecting the environment and fighting pollution in any of its forms". The impacts that affect local, regional, and national economic development rely on the fact that it spreads its coverage. In fact, the social and political issues go beyond the boundaries of environmental policies which are on the agen-

\footnotetext{
*Address for correspondence: Andréa Cristina Trierweiller, Dr., Production Engineering Department, Federal University of Santa Catarina, 476, Zip Code 88040-900, Campus Universitário, Trindade, Florianópolis, SC, Brazil. Tel.: +55 48 37217071; Email: andreatri@gmail.com
} 
da of various communications media as a major topic today.

Concern for the environment has highlighted the importance of deploying an environmental management system, which can provide holistic and systemic management. According to Kaplan and Norton's [18] assertion that it is impossible to manage something which you cannot measure reinforces the importance of using a method which provides a perspective of the business through analyzing the results of the principle strategic management perspectives. This will help executives to assess and achieve decision-making goals or to correct their courses to ensure that such objectives are achieved. In this context, there is a need for organizations to effectively manage their information resources and to obtain knowledge to assist the decision-making process.

According to Hronec [17], performance measurements are vital signs for an organization, confirming that environmental management requires the use of performance measurements to qualify and quantify how the activities of a process achieve their goals.

The Environmental Management System according to ISO 14001 is one of the most used by companies in Brazil. This system aims to provide organizations with the elements of an effective environmental management system that integrates with other management requirements to help to achieve environmental and economic goals. [...] Environmental management encompasses a wide range of issues, including those with strategic and competitive implications [25].

Within this context, the objective of this article is to verify the viability of using the Item Response Theory to measure Environmental Management evidence among industrial companies in Brazil, considering the sectors analyzed and based exclusively on information available in these companies' websites. The intention of such measurement is thus to evaluate the quality and propriety of each item individually, placing items and respondents on a single scale.

After presenting the definition of the problem as refers to this article, this paper is structured as follows:

- Part Two is the methodological background (principle and/or approach).

- Part Three is the theoretical development (fundamentals);

- Part Four presents a survey based multi-case study in five Brazilian Industrial economic sectors (1) Paper, (2) Steel and Metals, (3) Energy, (4) Chemical and Petro-chemical, (5) Agricul- tural production, (6) Construction, (7) Auto industry ;

- Part Five is critical evaluation against related works, and the conclusion.

\section{Methodological background}

\subsection{Item Response Theory (IRT)}

The mathematical models of the IRT estimate item and respondent parameters in order to establish a quantitative measurement scale. To estimate these parameters, one defines a set of variables which cannot be measured directly, but express a theoretical concept defined by "construct" or "latent traits", such as the "corporate environmental management performance" to be answered for a sample of manufacturers located in Brazil. The Item Response Theory (IRT) is a powerful tool that enables the construction of scales from a set of items via mathematical models $[12,16]$.

The construction of a set of items as well as a scale to measure the environmental management performance of industrials based on IRT is proposed. This study is structured as follows: (1) the context of the study is presented, followed by an explanation of scale construction, the IRT, and industrial company environmental management performance; (2) the methodology is described; (3) the findings are presented and then discussed, and finally; (4) the conclusions.

It is possible to establish a scale to measure the Brazilian industrial environmental management performance and to follow its evolution over time. It is also possible that new firms, responding to all items, check what their level is on the scale. The scale can be constantly updated with the inclusion of new items, ensuring comparison by keeping the same established unit of measurement. This results in a calibrated item database in the performance range of environmental management, which can be extended to evaluate other industries throughout Brazil.

\subsection{Methodological procedures}

Gathering secondary data as well as bibliographic research to compose the study's theoretical reference was used as the methodological outline. The primary data collection, supported through evidencing environmental information (disclosure) occurred based exclusively on the company sites analyzed from the database of the Biggest and Best list as provided by 
Exame Magazine concerning the 7 sectors of this study [22]. Then, the researchers accessed respective websites of the companies selected and responded either "yes" or "no" to the items in the questionnaire. Thus, for the intents of this article, the industrial company environmental performance evaluation presents this delimitation and constitutes a basis to outline the current situation as well as bring together critical analysis, suggestions, and conclusions.

The inductive investigative method is utilized. As such, it starts from a particular premise, data, and confirmed facts and builds towards a general premise, a conclusion which contains unverified facts or situations. Gil [15] highlights that in inductive reasoning; one must not seek a priori generalization, but verify it based on observing concrete cases, sufficiently confirmed from such a reality.

The present study possesses a quantitative nature, related to the data collection instrument, which presents closed questions (yes or no), generating results which are thus analyzed quantitatively with a twoparameter logistic model under the Item Response Theory perspective. This study deals with exploratory research, as it seeks to provide a general view of the problem and to approximate, making it possible to gain greater familiarity and comprehension from the investigator with respect to the phenomenon under study [15]. Such an approach results in an upgrading of ideas. This investigation involves a multicase study in 7 economic sectors.

The techniques outlined and procedures utilized in collecting data were defined in 3 phases (Fig. 1): (1) Elaborating the items based on exploratory research in literature relevant to the environment, totaling 32 items; (2) Submitting the items to evaluation from 3 experts of the environmental area, with suggestions to improve the semantics and subsequent exclusion of 6 items; and (3), according Fig. 1:

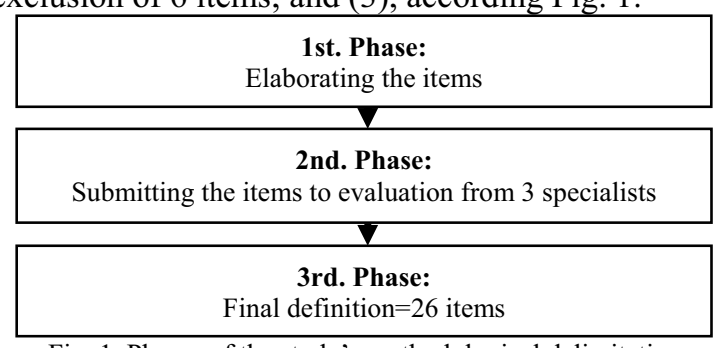

Fig. 1. Phases of the study's methodological delimitation

The 26 items, presented in Table 1:

Table 1

Final report of the items

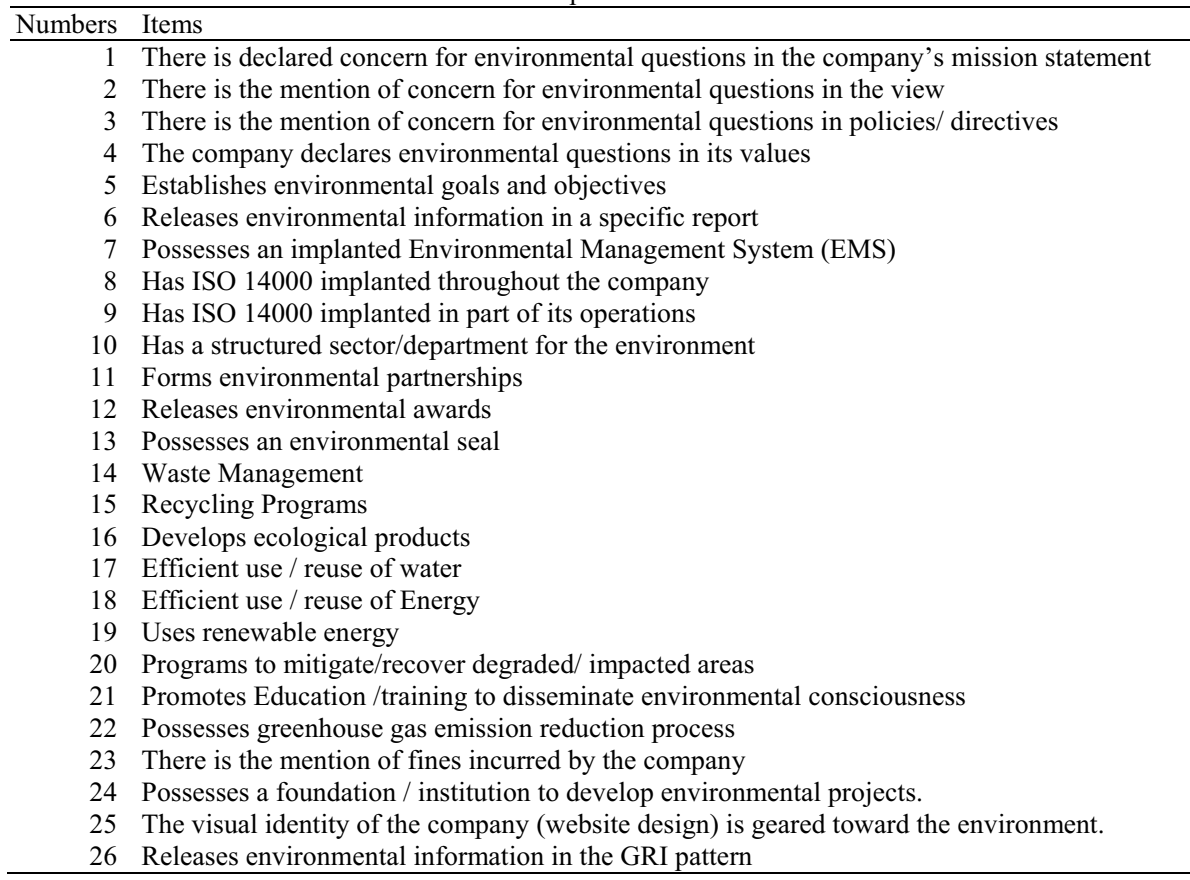




\section{Environmental management}

\subsection{The environmental question with a strategic focus}

Environmental management in Brazil has been researched by authors such as: Reis [30], Donaire [10], Viterbo Jr. [36], Moreira [23], Alexandre et al [2], Barbieri [3], Philippi Jr. et al [28], Tachizawa [34], and Shigunov Neto et al [31]. Environmental management may be defined as the set of management function activities which determine the environmental policy, objectives, and responsibilities of the company and place them into practice through intermediaries of the environmental system, environmental planning, environmental control, and environmental management improvement. As such, environmental management is the efficient management of the organization's relationship with the environment [31]

Companies seek to demonstrate and secure effective and efficient environmental performance control in order to reach sustainable development within the objectives and goals de-fined by high management. In order to do so, it is necessary to integrate the components of company environmental management, evidencing the diverse areas involved in the organization's structure. This view points to implementing policies and directives which orient the decision making process in all the actions developed in order to demonstrate the permanent strategy of investing through environmental management systems in the generation of expected results, defined in the objectives outlined by organizations.

Nascimento et al. [24] defines the Environmental Management System (EMS) as: the set of procedures which will help the organization to understand, control, and reduce the environmental impacts of its activities, products, and/or services. They also add that an efficient EMS permits companies to improve the management of environmental aspects and impacts, beyond interacting in changing organizational attitudes and cultures, improving its results in economic terms upon acting towards the continued improvement of processes and services. Barbieri [3] also highlights the importance of placing environmental issues strategically in the organization.

Based on the results of the EMS, the company must carry out critical analysis in order to at-tend its stakeholders' demands and legal aspects in seeking constant perfection. It is thus fundamental to contemplate the environmental management areas with critical analysis, based on a total environmental evaluation, as shown in Fig. 2:

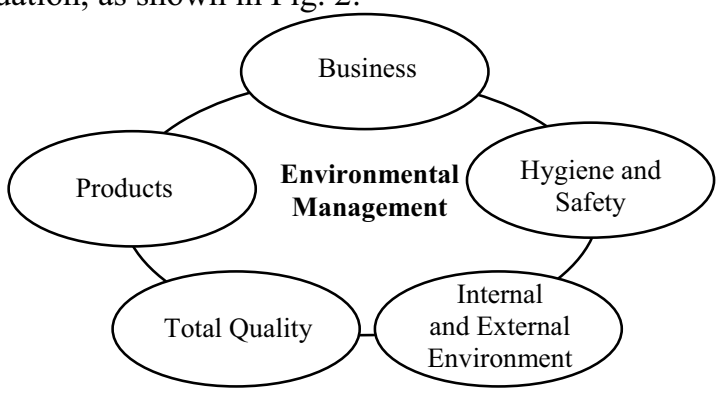

Fig. 2 . Components of Environmental Management, evidencing the environmental component.

The integration of these concepts provides the company with a differential which is recognized and valued by the market. However, it cannot be represented or directly measured through a single element, but rather through a set of attributes which can evidence competitive advantage. Thus, according to Shigunov Neto et al [31], Environmental Management must be integrated to companies' activities as it deals with a systematic view, as shown in Fig. 3:

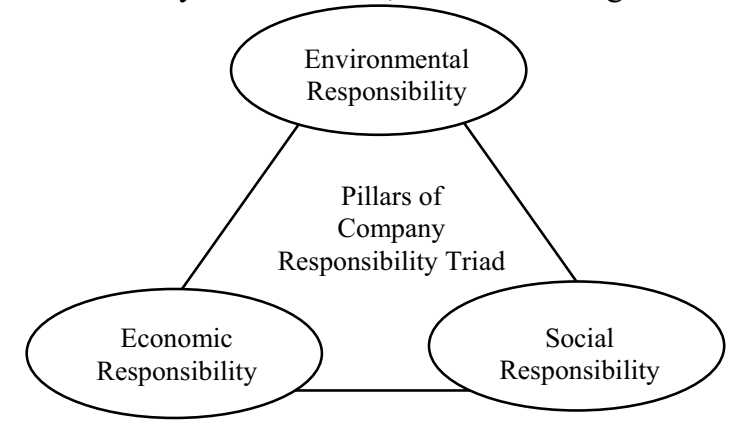

Fig. 3. Pillars of Responsibility: Environmental Management. Source: Elaborated from Shigunov Neto et al. [31].

Within this context, this integration of the pillars of the environmental responsibility triad give sustenance to companies' environmental management principles makes it evident that responsibility is diluted through all the areas of the organization, within a systematic view. Thus, analyzing adequate environmental management is a complex task. To this light, the measurement tool as defined by this study is the "Item Response Theory", as it presents mathematical and statistical models which create a scale to represent industrial company environmental management performance.

The expression Corporate Social Responsibility (CSR) has acquired the most varied definitions. The beginning of discussions within the theme, geared towards business, according to Carroll [6] began in the 1950s. This author considers Bowen [5] to be the 
principle source of the beginning of the debate in 1953, with the following questioning, "Which responsibilities must be expected that businessmen assume on behalf of society?"

According to Lindgreen et al. [21], organizations who believe they must "give something back" to society have adopted the Social Corporate Responsibility concept.

Organizations exist within large networks which consist of various groups (stakeholders) who exercise pressure upon them. A good corporate citizen should respond to the stakeholder demands which may directly or indirectly affect the organization's activities or be affected by them $[11,37]$.

\section{Multi-case study}

\subsection{Economic sectors studied}

The companies analyzed in this article involve 7 (seven) economic sectors. The industrial companies analyzed herein are ordered according to the "Sales" criteria. The data was taken from the Brazilian magazine, Exame [23], in its annual ranking of the Biggest and Best companies performing in Brazil. Among them are national and international companies, bringing the total sample size to 270 companies under analysis. This research was carried out from May to August of 2011.

- Paper. This includes industries which produce pulp, involving separating the paper fibers from the wood or recyclable paper through mechanical or chemical processes. Paper is obtained through the conversion of these fibers into sheets, and its products are formed through cutting, modeling, coating, and lamination processes [26, 33].

- Steel and Metals. Industries which operate within the set of procedures and techniques to extract, manufacture, found, and treat metals and their alloys. Metals are used to manufacture utensils, materials such as copper, lead, bronze, iron, gold, and silver, which were amply used in the past. The first foundries appeared in the 8th Centuries. The metals industry had resurgence in the 18th century with the industrial revolution [32].

- Energy. This sector involves companies which generate and distribute electrical and bioelectrical, thermo-dynamic, and hydro-electrical energies [23].
- Chemicals and Petrochemical. The petrochemical industry is part of the chemical industry. It is characterized through its use of petroleum (naptha) or natural gas derivatives as primary materials. However, many of the products denominated as petrochemical, such as polyethylene, for example, may be obtained either through these raw materials or through others, such as coal (South Africa) or alcohol (Brazil). The official classifications of the chemical industry have not utilized a separate "petrochemical" concept. Such industries supply raw materials and products to diverse productive sectors, from agriculture to aerospace $[1,29]$.

- Agricultural Production. This sector has seen the modernization of agricultural activities based on the Green Revolution technological paradigm, which has gone through great modification in the productive structure of the fields. This has benefitted large landowners with the exploration of export products, propelled by globalization and the opening of international economies, in large part among the most industrialized regions of Brazil [27].

- Construction. The peculiarity of this sector resides in its resistance to professionals involved in assuming the uncertainty risks of changing its status quo. Such resistance, added to the multidisciplinary nature of the projects which at times signify an involvement from various companies and the sector's dependence on research for new materials and equipment, has kept civil construction from modernizing to the pace of other productive sectors [14].

- Auto industry. In general terms, one can characterize the evolution of this relatively new industry in principle markets through the advance of globalization, through intensified competition herein included the intensification of the introduction of new Technologies -, and through the reduction of competitive differences among the leading manufacturers: (...) competitive strategies implemented by automakers in recent years as well as an evaluation of their respective performances in primary automobile markets $[7,8]$.

\section{Results and discussion}

Table 2 demonstrates the estimated parameters for the 26 items based on the sample of 270 companies from the sectors under analysis. These items were ordered according to their Level of difficulty, repre- 
sented by the parameter " $b$ ". The parameters were estimated according to a normal distribution $\mathrm{N}(0,1)$, in other words with a mean of zero and a variance of one.

Table 2

Parameters of the ordered items according to degree of difficulty (expressed by the parameter b)

\begin{tabular}{|c|c|c|}
\hline Items & $\mathrm{a}$ & $\mathrm{b}$ \\
\hline 14 & 5.509 & -0.241 \\
\hline 17 & 5.75 & -0.139 \\
\hline 7 & 2.05 & -0.120 \\
\hline 15 & 3.656 & -0.084 \\
\hline 21 & 3.349 & -0.076 \\
\hline 3 & 3.023 & -0.058 \\
\hline 18 & 6.157 & -0.042 \\
\hline 25 & 2.808 & 0.039 \\
\hline 9 & 1.285 & 0.089 \\
\hline 20 & 4.42 & 0.179 \\
\hline 16 & 3.785 & 0.214 \\
\hline 22 & 2.152 & 0.219 \\
\hline 5 & 3.246 & 0.220 \\
\hline 19 & 4.181 & 0.252 \\
\hline 11 & 4.109 & 0.304 \\
\hline 6 & 3.908 & 0.328 \\
\hline 4 & 1.427 & 0.405 \\
\hline 12 & 2.183 & 0.452 \\
\hline 10 & 3.585 & 0.455 \\
\hline 1 & 1.494 & 0.557 \\
\hline 24 & 3.812 & 0.605 \\
\hline 26 & 3.769 & 0.662 \\
\hline 13 & 2.037 & 1.001 \\
\hline 2 & 1.192 & 1.045 \\
\hline 8 & 0.554 & 1.437 \\
\hline
\end{tabular}

In practical terms, based on the parameter $b$, it is more probable that companies which have a degree of Environmental Management evidence surrounding the mean (in this case, zero) possess the majority of the characteristics evidenced in the items. Merely 3 items demonstrate a greater level of difficulty, with one above 1 . These items are: item $13(b=1.001)$, item $2(b=1.045)$, and item $8(b=1.437)$. Thus, the company must be able to attend the set of items elaborated in order to evidence its Environmental Man- agement. In other words, the instrument as a whole showed low levels of difficulty.

Item 8 is the most difficult of the $26(b=1.437)$, meaning that the majority of the organizations did not provide evidence of having the ISO 14000 implemented throughout the company. However, this item showed low discriminatory power, as represented by the parameter $(\mathrm{a}=0.554)$. This parameter represents the item's quality with respect to its information. In other towards, items with low "a" values (generally less than 0.7 ) are considered to be uninformative, 
according to Tezza et al. [35]: “(...) a low discrimination parameter of a $<0.700$, which indicated items offering little information and possibly not directly related to the latent trait".

Item $10(b=0.455)$, also showed itself to be difficult to achieve, meaning that companies evidenced having a sector/department structured towards the environment. This is the same behavior shown through item 12, referring to the release of environmental awards, with both items being above average. They also presented good discriminatory power, representing quality items for the construct, in statistical terms.

Item $13(b=1.001)$, which refers to the environmental seal, is characterized as difficult for companies to evidence.

Item $14(b=-0.241)$ showed itself to be the easiest. This means that the large majority of the companies involved have Waste Management in order to demonstrate their Environmental management. The "average" company shows around a 0.75 probability in having this characteristic.

Items 16 (develops ecological products), 22 (possesses a greenhouse gas emission reduction process), and 19 (uses renewable energy), with respective "b" parameters of $0.214,0.219$, and 0.252 , showed to be very close in their positioning on the scale, which indicates they are at the same level as attending Environmental Management evidence.

In item $3(b=-0.058)$, one observes that the majority of the companies present the mention of concern for environmental questions in their strategic policies and directives. This may be related to the fact that the definition of environmental variables inserted into the organization's directives is guided by its strategy to simulated scenarios within the environmental conjecture. Thus, one verifies the company tendency to initiate their strategic planning with focus, including in sustainability questions, concerning themselves primarily with their environmental policy definition.

Item $2(b=1.045)$, the second most difficult, demonstrates that not all companies mention concerns for environmental questions in declaring their vision. However, the mission statement and its values, respectively represented by items $1(b=0.557)$ and 4 $(b=0.405)$, present themselves as above average. They demonstrate greater evidence as these three items are inherent to the company's strategic formulations.

Fig. 4 refers to the total information curve, which is represented by the sum of the information from all the items. It demonstrates that the construct presents greater precision surrounding the mean in order to measure the Degree of Evidencing Company Environmental Management among the sectors analyzed.

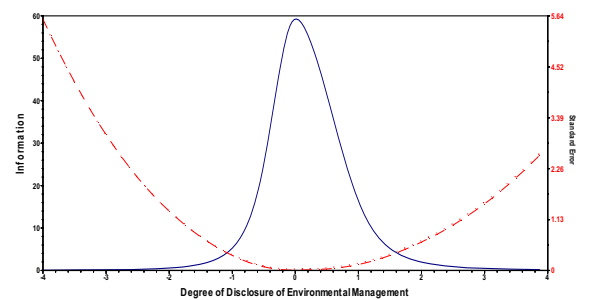

Fig. 4. Total information curve for the test (function test information: continuous line; standard error of measurement: dotted line).

\section{Conclusion}

Based on the resulted obtained, one can verify the viability of measuring and thus evidencing Environmental Management among the companies in the analyzed sectors, using the IRT. In fact, it has presented many advantages with respect to item selection in composing the questionnaire, as it permits quality and propriety evaluation for each item individually while placing them within a single scale: items and respondents, which is not possible through the use of other tools. This is particularly useful when evaluating constructs which are difficult to observe or abstract, such as evaluating company Environmental Management.

One can observe a clear order of the items based on each item's estimated level of difficulty as well as each item's quality. Thus, characteristics related to certification are verified as little practiced by companies, as items 8, 13, and 26 in the scale generated possess a greater level of difficulty than the remaining items, considering that these three items are related to certification.

As to the limitations of the company Environmental Management Evidence evaluation questionnaire, presented in Table 1, construction of a greater number of items is suggested, as well as their submission to a greater sample of companies. Thus, would be able to perform an analysis by sector of activity.

\section{References}

[1] Abiquim, Associação Brasileira da Indústria Química, 2011, Retrieved on ago, 2011, from http://www.abiquim.org.br/elementos.asp?pag=perg

[2] J.W.C. Alexandre, D.F. Andrade, A.P. Vasconcelos and A.M.S. Araujo, Uma proposta de análise de um construto para a medição dos fatores críticos da gestão pela qualidade através da teoria da resposta ao item, Gestão \& Produção, v.9, 2(2002), 129-141. 
[3] J.C. Barbieri, Gestão ambiental empresarial, Saraiva, São Paulo, 2004.

[4] I. Bodas, The Diffusion of ISO 9000 and 14001 Certification, Cross Sectoral Evidence from Eight OECD Countries, Paper Presented at the Summer Conference, Copenhagen Business School, Denmark, June, (2009), pp.17-19.

[5] H.R. Bowen, Social responsibilities of the businessman, New York: Harper \& Row, 1953.

[6] A.B. Carroll A, Three dimensional model for corporate performance, Academy of Management Review, v. 4, 4(1979), 497-505.

[7] E.G. de Carvalho, Globalização e estratégias competitivas na indústria automobilística: uma abordagem a partir das principais montadoras instaladas no Brasil, 274f. Tese, (Doutorado em Economia), Universidade de CampinasUnicamp, Campinas, 2003.

[8] E.G. de Carvalho, Globalização e estratégias competitivas na indústria automobilística: uma abordagem a partir das principais montadoras instaladas no Brasilm, Gestão \& Produção, v.12, jan.-abr, 1(2005), 121-133.

[9] Brasil, Constituição 1988, Constituição da República Federativa do Brasil, Brasília, DF: Senado Federal

[10]D. Donaire, Gestão ambiental na empresa, São Paulo: Atlas, 2000.

[11] T. Donaldson and L. E. Preston, The stakeholder theory of the corporation: concepts, evidence, and implications, Academy of Management Review, 20(1), (1995), 65-91.

[12] S.E. Embretson and S. P. Reise, Item response theory for psychologists. Lawrence Erlbaum Associates, New Jersey, 2000.

[13]F. Franceschini, M. Galetto, L. Mastrogiacomo and L. Viticchie, Diffusion of ISO 9000 and ISO 14000 certification in Italian commodity sectors, International Journal of Quality \& Reliability Management 25 (5), 2008, 452-464.

[14]I. Francklin Jr and T.G. Amaral do, Inovação tecnológica e modernização na indústria da construção civil, Scientiae et Praxis, v. 1, n.2, 2008.

[15]A.C. GiL, Como elaborar projetos de pesquisa, Atlas, São Paulo, 2010.

[16] K. Hambleton, H. Swaminathan and H. J. Rogers, Fundamentals of item response theory, Newbury Park, Sage, CA, 1991.

[17] S.M. Hronec, Sinais vitais, Makron Books, São Paulo, 1994.

[18]R.S. Kaplan, D.P. Norton, Mapas estratégicos: balanced scorecard: convertendo ativos intangiveis em resultados tangiveis, Elsevier, Rio de Janeiro, 2004.

[19] A.A. King, M.J. Lenox and A. Terlaak, The strategic use of decentralized institutions: exploring certification with the ISO 14001 management standard, Academy of Management Journal, 5, vol. 48, 6(2005), 1091-1106.

[20]A. Lagodimos, P. Chountalas and K. Chatzi, The state of ISO 14001 certification in Greece, Journal of Cleaner Production, 15, 18 (2007), 1743-1754.

[21]A. Lindgreen, V. Swaen and W.J. Johnston, Corporate social responsibility: an empirical investigation of U.S. organizations, Journal of Business Ethics, 85(Suppl. 2), (2009), 303-323.

[22] Maiores e Melhores, Maiores empresas por vendas em 2010, Revista Exame, Retrieved on ago. 2011, from http://exame.abril.com.br/negocios/melhores-e-maiores.

[23] M.S. Moreira, Estratégia e Implantação do Sistema de Gestão Ambiental, Modelo ISO 14000, Desenvolvimento Gerencial, Belo Horizonte, 2001.

[24]F.L. Nascimento, A.D. da C. Lemos and M. C. A. de Mello, Gestão socioambiental estratégica, Bookman, Porto Alegre, 2008 .
[25]Nbr ISO 14001:2004, Inmetro 2011, Instituto Nacional de Metrologia, Normalização e qualidade industrial, Retrieved on Jan. 2011, from http://www.inmetro.gov.br.

[26]Advfn, Papel, Retrieved on jul. 2011, from http://br.advfn.com/mundo/brasil/setores/producao-industrialmadeira-papel-quimicos/papel

[27] S.E. Peixoto, A pequena produção agrícola: algumas questões atuais, Revista Bahia Agrícola, v2, 3(1998), Retrieved on jun. 2011 ,

http://www.seagri.ba.gov.br/revista/rev_1198/questoes.htm

[28] A. Philippi Jr, M. de A. Roméro and G.C. Bruna, Curso de gestão ambiental, Manole, Barueri, 2004.

[29]Thorium, Química e Petroquímica, Retrieved on: http://www.thorium.com.br/index.php?optin=com_content\&ta

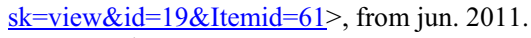

[30] M.J.L. Reis, ISO 14000: gerenciamento ambiental, novo desafio para competividade, Qualitymark, São Paulo, 1996.

[31]A. Shigunov Neto, L.M. de S. Campos, Fundamentos da Gestão Ambiental, Ciência Moderna, Rio de Janeiro. 2009.

[32] Simemae, Sindicato Intermunicipal das Indústrias Metalúrgicas Mecânicas e do Material Elétrico de Mato Grosso do Sul. 2011. Retrieved on jul. 2011, from http://simemae.com.br/portal/?p=7.

[33]P.E. de Souza, Implantação de Sistema de Gestão Ambiental em indústria de embalagens de papel, Dissertação (Mestrado em Engenharia Ambiental), Universidade Federal de Santa Catarina, Florianópolis, 2009.

[34]T. Tachizawa, Gestão Ambiental e responsabilidade social corporativa, Atlas, São Paulo, 2005.

[35] R. Tezza, A.C. Bornia and D.F. de Andrade, Measuring web usability using item response theory: principles, features and opportunities. Interacting with Computers, 23(2011), 167-175.

[36]E. Viterbo Jr, Sistema Integrado de Gestão Ambiental, Aquariana, São Paulo, 2000.

[37] S. Waddock, Integrity and Mindfulness: foundations of corporate Citizenship, in J. Andriof and M. McIntosh (eds.), Perspectives on corporate citizenship, Greenleaf Publishing, Sheffield UK, 2001, pp. 26-38. 